\title{
The Conflict between Preserving a 'Sacred Natural Site' and Exploiting Nature for Commercial Gain: Evidence from Phiphidi Waterfall in South Africa
}

\author{
Ndidzulafhi Innocent Sinthumule *(D), Thendo Mugwena (D) and Mulalo Rabumbulu (D)
}

Citation: Sinthumule, N.I.;

Mugwena, T.; Rabumbulu, M. The Conflict between Preserving a 'Sacred Natural Site' and Exploiting Nature for Commercial Gain: Evidence from Phiphidi Waterfall in South Africa. Sustainability 2021, 13, 10476. https:// doi.org/10.3390/su131810476

Academic Editor: Brian Garrod

Received: 26 August 2021

Accepted: 14 September 2021

Published: 21 September 2021

Publisher's Note: MDPI stays neutral with regard to jurisdictional claims in published maps and institutional affiliations.

Copyright: (c) 2021 by the authors. Licensee MDPI, Basel, Switzerland. This article is an open access article distributed under the terms and conditions of the Creative Commons Attribution (CC BY) license (https:/ / creativecommons.org/licenses/by/ $4.0 /)$.
Department of Geography, Environmental Management and Energy Studies, University of Johannesburg, P.O. Box 524, Auckland Park, Johannesburg 2006, South Africa; thendom@uj.ac.za (T.M.); mrabumbulu@uj.ac.za (M.R.)

* Correspondence: isinthumule@uj.ac.za
Abstract: Over the years, the Phiphidi sacred natural site has been protected by traditional methods or cultural codes. However, over the past three decades, anthropogenic pressures have affected the site. This study aimed to investigate the historical uses of the Phiphidi sacred natural site and contemporary anthropogenic threats to the area, and the implications on the sustainability of the area. The data supporting this study were collected between June 2018 and May 2021, during which (i) interviews, (ii) observations and (iii) documents were used as the main techniques of data collection. Non-probabilistic purposive (also known as judgemental) sampling was used to select respondents including the custodians of the Phiphidi sacred natural site, officials working at Phiphidi Waterfall, representatives of the Dzomo La Mupo committee and local communities. The data obtained from interviews were analysed using thematic content analysis. Field observations helped in validating the data that were collected through interviews. The study showed that although the sacred site was historically a 'no go area' and was used to connect with ancestors and perform rituals, contemporary anthropogenic threats affecting the Phiphidi sacred site include weak property right systems and tourism infrastructure development that has led to land-use conflicts that have been driven by vested interests. The contemporary practices not only undermine the Vhavenda culture but also have negative implications for the biodiversity of the area. In addition, the current practices undermine the founding principles of the 1996 Constitution of the Republic of South Africa; these embrace culture, religion and the country's environmental laws. While passion to save the sacred sites by custodians and local communities is still alive, government support is weak and, as a result, there are fears that other sacred sites in the region may also be targeted for tourism purposes. Several suggestions are made that, if implemented, could help to protect the remaining sacred natural sites.

Keywords: sacred natural sites; tourism development; land-use conflicts; Phiphidi Waterfall; ancestors; custodians

\section{Introduction}

The Vhavenda community is located in the northern part of present-day Limpopo Province in South Africa. Although they live in other provinces of South Africa, they dominate in and around the Soutpansberg Mountains in the north-eastern part of South Africa. The Venda area shares borders with south Zimbabwe and south-eastern Mozambique [1]. Whilst some historical accounts suggest that the Venda people came from the Congo region, others maintain that they originated from the Great Lakes of Central Africa, migrating south in waves over centuries [2]. Oral tradition suggests that most of the significant migrations to the current territory known today as Venda came from north of the Limpopo River (Zimbabwe) in the 17th and 18th centuries [1]. The Vhavenda community is among the nation's most traditional societies. Ancestor worship and rituals in sacred natural sites (termed Zwifho) are at the heart of Vhavenda culture. Water holds a special 
place and throughout Venda, sacred rites are performed at water sources such as Lake Fundudzi, Phiphidi Falls and the Mashovela sacred pool. Other sacred sites include the forests, mountains or hills and caves. These sites are places where the ancestors reside. For instance, Thathe Vondo forest is guarded by a white lion that protects the ancestors of the Netshidzivhe clan [3]. Entry to these sites is forbidden to all but the custodian clan; hence, such places are 'no go areas' for others because of the taboos associated with entering such spaces. The Vhavenda sacred natural sites are, therefore, highly respected places, and even speaking about them is forbidden in some circles [3,4]. The rituals and ceremonies are performed by an elderly women (Makhadzi) selected from the custodian clan; it is her responsibility to help maintain the potency of sacred natural sites, but importantly, also the well-being of all life. Thus, the rituals and ceremonies performed by Makhadzi enable the ancestral spirits to remain alive, in return for protection, governance and blessings [5]. The Vhavenda sacred natural sites in the Vhembe region have remained undeveloped for tourism purposes because any kind of development will anger the ancestors. However, Phiphidi Waterfall—a 'sacred natural site' - has recently been developed into a tourist attraction. This has led to conflict between the custodian of the Phiphidi sacred site and the developer. The study uses the Phiphidi sacred natural site to ask the following key research questions: What were the historical uses of the Phiphidi Waterfall? What are the contemporary anthropogenic threats to the Phiphidi Waterfall? Why have development and tourism in a sacred site created conflict between the custodians and the developers? What are the implications of tourism development on a sacred site? The Phiphidi waterfall case study is used to guide the discussion of this paper and to identify the actions required by communities and the authorities.

\section{Understanding Sacred Natural Sites}

In many religions, it is believed that nature is the dwelling place for gods. For instance, the Germans, Britons, Finns and Celts worshipped under specific trees in their pre-Christian history. Similarly, the Hindus, Shintoists, Maris and several smaller cultures around the globe practise their religions in nature [6]. Those areas have been called sacred natural sites and are defined as 'areas of water or land having special spiritual importance to indigenous people' [7]. Sacred natural sites occur in various forms, including burial grounds and sites of ancestral or deity worship [3,8,9]. As Bhagwat and Rutte [8] have noted, sacred natural sites are found on all the continents except Antarctica. Examples of sacred natural sites include sacred groves in eastern Guinea-Bissau [10], Apra Hills sacred groves in Ghana [11], sacred shrines in southern Ethiopia [12], Indian sacred groves [13,14] and monastery gardens in Europe [15]. They incorporate places within the landscape including rocks, hills, mountains and caves; rivers, lakes, ponds, coastal water and islands; and forests groves; and other natural features that have a special meaning to people [16,17]. A wider category of sacred sites may also include human-built structures or monuments (such as temples) $[7,18]$. Sacred natural sites have been set aside by human societies for cultural and other needs since time immemorial $[12,19]$ and are considered hotspots for biocultural diversity [20-22]. They are globally significant because they embrace both cultural and biological diversities and serve as biocultural diversity hotspots $[12,18,19,21,23]$. Sacred natural sites are significant to human life because, among other purposes, they are burial sites for the custodians of such places [3], places for connecting with spirits and ancestors and sites for performing rituals that harbour deep cultural meanings to society $[4,24]$. They also serve the health needs of people by providing medicinal plants $[17,22]$; areas for contemplation, ceremony, meditation and prayer; and places that hold secular values for culture and history [7].

Sacred natural sites also play a significant role in conserving biodiversity because they are often located in regions that are rich in biodiversity, and cover a wide variety of habitats and landscapes $[20,24]$. These areas provide a home for trees that have been retained by communities and can be recognised as distinctive veteran trees. The big size and longevity of these veteran trees give them a lasting presence in the landscape as living artefacts 
of local history and culture $[17,25]$. The tall trees in sacred natural sites not only help to protect the soil and water but also help in storing carbon, particularly in urban areas [26]. In addition, these sites shelter a wide diversity of insects, macro-fungi, birds, mammals and other forest-dwelling animals as compared to the surrounding areas [24,27-29]. Sacred natural sites in landscapes that are cultivated also provide habitats and corridors that enable the movement of organisms [30,31]. It is argued that these sites constitute the world's oldest conservation areas by local communities [16], having been set up long before the introduction of formal conservation programmes [18]. Although sacred natural sites are generally small in size [7], they are nodes in a much larger ecological network that is an integral part of the social fabric that permeates the whole landscape or territory [19,32]. In addition, when aggregated globally, sacred natural sites may comprise 12 million $\mathrm{km}^{2}$ or at least $8 \%$ of the world's land surface [33]. Access to sacred sites (particularly human-built areas or monuments) may be open to anyone who shows respect [7]. However, very often, due to the spiritual values attributed to these sites, entrance into sacred natural sites is completely prohibited $[3,4,7]$.

Taboos, cultural rules and the fear of supernatural punishments have traditionally served as cultural codes to human perceptions of the sacred natural sites $[20,25]$. These traditional methods or cultural codes have maintained the latter sites in a natural or nearnatural state for centuries [3,17]. Thus, many such sites have not undergone deforestation, soil erosion or environmental degradation because they are deeply rooted in indigenous belief systems and cultural values [3,7,34]. However, as the older generation fades, the fears of supernatural punishment and taboos are also fading, even though they have been in place for centuries. These changes, accompanied by other anthropogenic pressures, have resulted in an increasing level of threat to sacred natural sites in many parts of the world $[8,12,16]$. This raises intriguing questions about the types of anthropogenic activities that are threatening sacred natural sites. Further, why are sacred natural sites targeted for development? It also needs to be asked what the implications are of anthropogenic activities on both cultural and biological diversities. We try to answer these questions using the Phiphidi Waterfall in Limpopo Province of South Africa as our case study.

\section{Material and Methods}

\subsection{The Study Area}

The study area is Phiphidi Waterfall $\left(22^{\circ} 55^{\prime} 60^{\prime \prime} \mathrm{S}\right.$ and $\left.30^{\circ} 24^{\prime} 0^{\prime \prime} \mathrm{E}\right)$, located in the foothills of the Soutpansberg Mountains-South Africa's northernmost mountain range [35]. The study area falls under Thulamela Local Municipality, which is situated in the Vhembe District in Limpopo Province (Figure 1). Phiphidi Waterfall is located at an elevation of 867 metres above sea level. The study area is positioned on the Mutshindudi River that originates on the southern slopes of the Soutpansberg mountain range. This river is a tributary of the Luvuvhu River, which flows through the Kruger National Park to join the Limpopo River [36].

The climate in the study area is warm and temperate. Phiphidi Waterfall is characterised by high annual rainfall (over $1500 \mathrm{~mm}$ per year) [37] and is often covered by mist, particularly in the morning. The study area is located in FOz 4 Northern Mistbelt Forests that are typically species-rich evergreen afrotemperate mist-belt elements and species of subtropical provenience, indicating a floristic link to the Scarp Forests [38]. The broader area is rich in biodiversity that supports hundreds of floras and faunas, some of which are endemic [39]. The most common trees in the Phiphidi Waterfall area include Croton grattismus, Combretum zeyheri and Ficus natalensis. Climbers such as Momordica foetida occur in the canopies of trees and shrubs. All the elements (the river, waterfalls and surrounding forest) are considered sacred. 


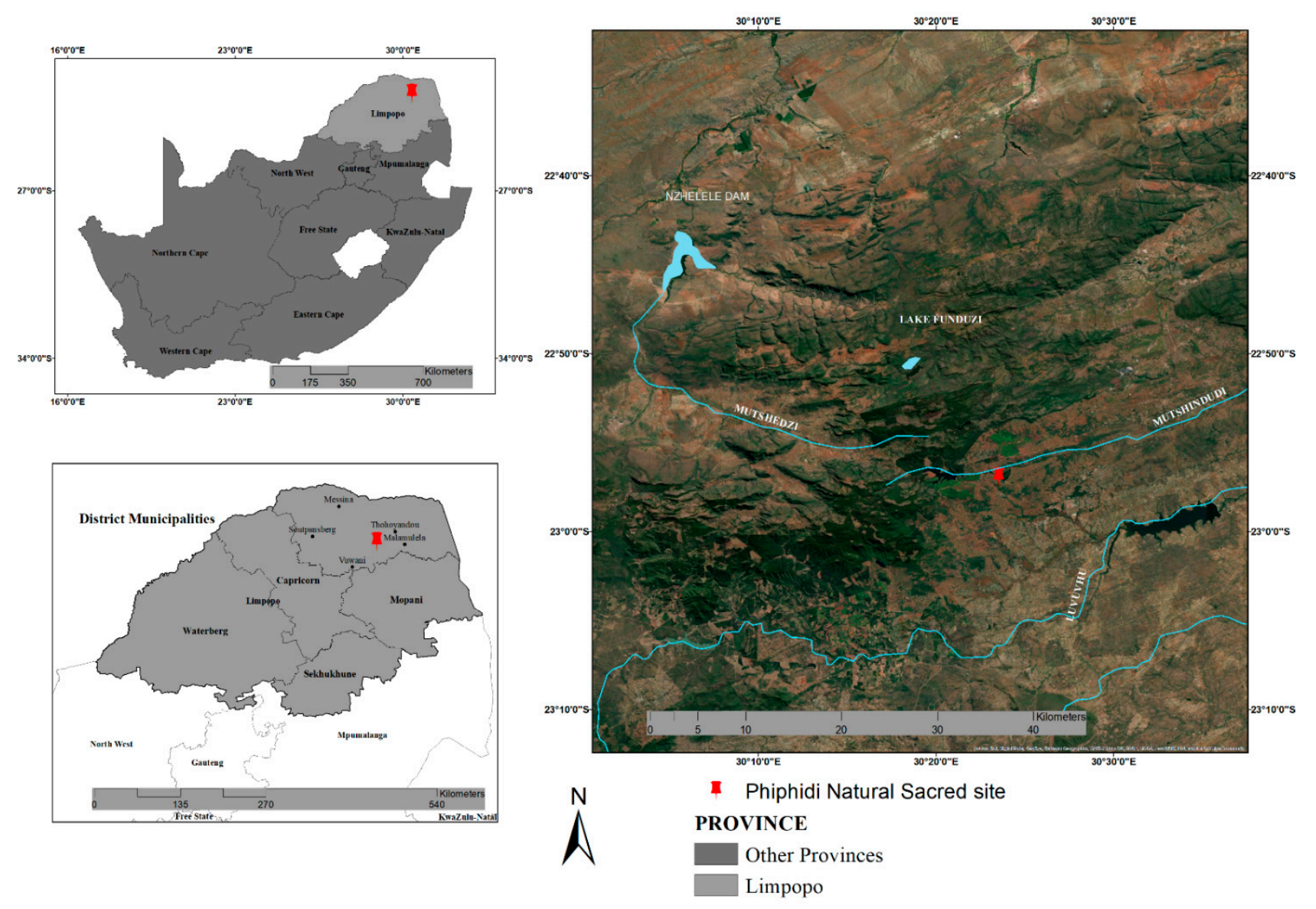

Figure 1. Location of the study area.

\subsection{Data Collection and Analysis}

The data gathering that supports this study was conducted between June 2018 and May 2021. The study relied on (i) interviews, (ii) observations (iii) and documents as the main sources of data. A non-probabilistic purposive (also known as judgemental) sampling technique was used to select respondents for the study. Purposive sampling is the intentional selection of respondents based on their ability to elucidate a specific theme, concept or phenomenon [40,41]. As Guest et al. [42] noted, in purposive sampling, there is no specific number of people required to be interviewed. As a result, informants were interviewed until the point of data saturation. The respondents of this study were the custodians of Phiphidi Waterfalls, officials at Phiphidi Waterfall, representatives of Dzomo La Mupo (a community committee whose name means 'voice of the earth') and other members of local communities.

Informants were asked for their consent before they were interviewed, and they were informed about the aim and scope of the research. Respondents were promised that their participation was voluntary and that their contribution would not be revealed to anyone. To fulfil this promise, the names of informants are not exposed in this article. However, as a testament to the commitment they feel to this topic, some respondents only participated in this study on the condition that their names should be revealed. The names of the latter respondents have, thus, been included in the write-up.

Semi-structured interviews were found to be appropriate to this study because they are flexible and allow for an open discussion that can go beyond the restrictions set by the interview schedule. The interview questions were aimed at building an understanding of the historical uses of the Phiphidi Waterfall sacred area, tourism development in the Phiphidi sacred site and implications of tourism development on the sacred site. Interview 
length ranged from 45 to 90 min and all answers given by informants were written in a notebook.

Data obtained from the semi-structured interviews were analysed using thematic content analysis, a qualitative analytic method of 'identifying, analysing and reporting patterns (themes) within data' [43]. From the information gathered, the researchers read the transcribed notes critically in order to gain understanding of the data [44]. The interview excerpts from informants were tabulated on Microsoft Excel and key phrases were highlighted according to categories. In line with [44], the collected data were then arranged into groups identified by various codes, and this permitted us to obtain summarized key points and common meanings that recurred throughout the data. From the codes, patterns were identified, and we came up with the following three themes: historical use of Phiphidi Waterfall sacred area, tourism development in the sacred site and implications of tourism development on the sacred site. These themes are discussed further below. Following [45], experiences were recounted in the write-up using the same words of the informants. Field observations helped in validating the information that was collected through interviews. These also enabled observations of activities happening in the sacred site to be made and new developments in the area to be noted.

Secondary data sources included newspaper articles, journals articles and reports written about Phiphidi Waterfall sacred site. These sources of information were analysed and synthesised to develop descriptions that replicate the historical use of the Phiphidi Waterfall sacred area, how tourism developed in the sacred site and the implications of these uses of the area. In the same manner, incidents or events from secondary data were described in the write-up using the same words of respondents, to provide a vivid narrative of the situation for the reader.

\section{Results}

\subsection{Historical Use of Phiphidi Waterfall Sacred Area}

The Phiphidi Waterfall is of fundamental ecological, cultural and spiritual importance to the nearby Venda communities who are the indigenous people of the region. Among the Venda communities, the Ramunangi (Vhadau) clan of the Vhangona people are the acknowledged ancient custodians of Phiphidi Waterfall, consisting of the two sacred ritual sites known as Lanwadzongolo (the sacred rock above the waterfall) and Guvhukuvhu (the pool below the waterfall) [46]. As one elder member of the family narrated:

'We are Vhonganiwapo (indigenous people) who were chosen to have Zwifho (sacred sites) by Ri sa mudi or Nwali (Creator or God). We are identified by mutupo (totems) and we protect anything that survive within our sacred sites. This includes living organisms that live inside and outside water. Not everyone have sacred sites, not even the chiefs and kings have sacred sites. We are the chosen one by Nwali (Creator or God) to do rituals in sacred site for the benefit of all people' (Interview, custodian member, 27 April 2021). Nwali, in this case, is a universal God who is the only creator of humankind on earth. Nwali is regarded as the provider of rain, which Vhavenda people depended on for their survival. He is also the protector and defender of Vhavenda people. The quotation above is in line with the centuries-old belief among all the Venda people that different clans are tasked with performing certain rituals on behalf of the entire group [35]. This special relationship between the Ramunangi clan (the custodian) and the Phiphidi Waterfall sacred sites is recognized by all Venda-speaking people-and in particular, those who live in the nearby areas of Phiphidi and Thohoyandou. The Mutshundudi River is considered sacred, and the waterfall is believed to be home to the Zombies (Zwidudwane)—water spirits who reside in both the waterfall and the pool (Interview, custodian member, 28 April 2021). Thus, the ancestors or spirits reside in the water. These spirits require beer and grain offerings as they are not able to acquire their own. At Phiphidi Waterfall, these offerings used to be made on a sacred rock near the top of the falls, known as Lanwadzongolo, as well as below the waterfall known as Guvhukuvhu. The offerings are important because they keep a good relationship with the spirits and ancestors (Interview, Mphatheleni Makaulula, 27 April 2021). The Ramunangi clan, who 
are the custodians, were responsible for performing these rituals because only they could obtain the desired results from their ancestors. Although, traditionally, these offerings were performed throughout the year, the Thevhula, which was an annual offering ceremony, was an essential part of the spiritual life of Ramunangi people and is still performed at many of the sacred sites in the Venda area. These rituals were only performed by women, known as Makhadzi-women of power. During each ritual, snuff (tobacco) and traditional beer (mahafhe) is sprinkled on the ground as the Makhadzi speak with the ancestors. Men could be present, but only women could speak to the ancestors during the rituals. This ritual (Thevhula), which lasted for days, was considered to be essential to ensuring good rain, health, agricultural abundance and community peace (Interview, custodian member, 28 April 2021).

From time immemorial, the Phiphidi Waterfall has been used for ritual purposes by the Ramunangi clan; hence, the area is considered a sacred site. Prohibitions, taboos and cultural rules have governed clan practice and behaviour in the Phiphidi sacred natural site [39]. The rituals that used to be performed at the waterfall-until the construction of the tourist facilities that prevent this-have played a significant role in the protection of the area from the public over the centuries. The Lanwadzongolo and Guvhukuvhu sites in the Phiphidi Waterfall have traditionally been off-limits to all people except the Ramunangi clan (Interview, custodian member, 28 April 2021); this, in turn, has contributed to the area remaining a biodiversity hotspot. It was also believed that any person (besides the Ramunangi clan themselves) who enter the most sacred sites (namely Lanwadzongolo and Guvhukuvhu) might not come back. For instance, several people who have tried to swim in the Guvhukhuvhu pool sacred site at the foot of the waterfall have drowned. Thus, the spirits hold the local people responsible for the bad behaviour of entering the most sacred site. This belief and its associated laws have, therefore, protected the area from destruction for centuries (Interview, custodian member, 28 April 2021).

\subsection{Phiphidi as a Tourism Destination}

Tourism in Phiphidi Waterfall started during the apartheid era under the Venda 'bantustan' or 'homeland'. The Venda bantustan that was established by the apartheid government gained independence in 1979. After the Venda bantustan gained independence, the Venda Development Corporation-with the support of the local headman Tshivhasedecided to develop the Phiphidi Waterfall as a tourist destination area (Interview, custodian member, 28 April 2021). The development began with the construction of roads, the building of public restrooms and picnic areas and the construction of a border fence that still surrounds the area [39]. These developments were against the prohibitions, taboos and cultural rules that had been practiced since time immemorial. The structures such as ablutions and the internal roads contributed significantly to the fragmentation of the natural forest in the area. While the Ramunangi clan is credited as the custodian of Phiphidi waterfall, the development happened without consultation (Interview, custodian member, 28 April 2021). In addition, the precise extent and significance of the sacred site were not determined, nor was any effort made to negotiate the type and nature of the tourism infrastructure envisaged by the developers. The likely social and environmental impacts of the development were also not assessed before construction began (Interview, custodian member, 28 April 2021). The Ramunangi elders were deeply pained by the developments, but felt powerless to fight against the apartheid government [46]. However, tourism in the sacred site did not deter the Ramunangi clan from performing rituals. Rather, they went 'underground' to continue performing their rituals, despite the lack of approval from the authorities (Interview, custodian member, 28 April 2021).

With the end of apartheid in 1994 and the start of democracy, Phiphidi fell under the jurisdiction of the provincial government, namely the Northern Province Development Corporation, who have recently been replaced by the Limpopo Development Agency. The end of apartheid presented some hope that the Ramunangi could re-establish the custodial rights that they had once enjoyed. However, this did not happen, rather, the 
Ramunangi clan remain sidelined in democratic South Africa. Despite Phiphidi being legally part of a tribal area where communal ownership of property is recognised, there is presently no legislation giving legal custodianship status to the clan. Thus, despite the clan being the acknowledged custodians of Phiphidi Waterfall, they do not have property rights over the area. As a result, the construction of a road from Phiphidi to Donald Fraser Hospital in August 2007 destroyed the sacred rock of Lanwadzongolo, referred to above, and has irretrievably defaced the surrounding sacred forest [46]. The traditional authority of Tshivhase allowed the development of a quarry for making concrete for road construction on top of the sacred rock. The construction of the road not only destroyed the sacred rock of Lanwadzongolo but also led to the river where the ancestors live being polluted by diesel and sand, something that the Ramunangi clan viewed as an insult to the ancestral spirits (Interview, custodian member, 28 April 2021). In addition, in 2007, the local chief, Jerry Tshivhase, authorised a new tourism development project to be constructed by the Tshivhase Development Foundation Trust at Phiphidi Waterfalls, of which the Black Economic Empowerment billionaire Mashudu Tshivhase is a director. Both Jerry and Mashudu Tshivhase are related to Chief Kennedy Tshivhase, who is a leader of the Tshivhase Traditional Council (under which Phiphidi falls). Thus, construction was undertaken by an organisation connected to the royal family. This is in contradiction of the letter made public and that was signed by Chief Kennedy Tshivhase on 3 August 1995. This states that, ' . . in rural areas we have sacred forests that must never be tempered with in terms of modern developments and thus remain protected and honored by the authorities and the interested groups of the areas concerned'. Those in support of development see this as part of economic development, which will provide much-needed jobs to local communities (Interview, member in favour of development, 1 May 2021). Once again, this development was approved without consultation with the Ramunangi clan, as made clear by one of the family members who commented that, ' ... had we been informed as the custodian of Phiphidi waterfall, we could have advised on suitable places to develop. We are not against economic development; we are against development in a sacred site' (Interview, custodian member, 28 April 2021). The fact that the Ramunangi clan was sidelined can be attributed to the fact that they are not from the royal family, because other sacred sites that belong to the royal families such as Thathe and Vhutanda have not been developed.

Soon after the tourism development was sanctioned, the Ramunangi clan made efforts to meet with the local leaders responsible for development. However, the meeting requests were unsuccessful (Interview, custodian member, 28 April 2021). Their determination to meet with local leaders was to allow them to plead with them to stop development at the sacred site. Determined to obtain justice outside the tribal authority, in November 2008, the Ramunangi leaders drafted a legal claim of rights to the Phiphidi Waterfall sacred natural site. In the document, they requested the local, provincial and national governments to legally recognise them as the indigenous custodians of the Phiphidi Waterfall sacred natural site. They also requested that the tourism development taking place in the site should be stopped, the area should also be closed to the public and that the sacred site should be restored [46]. Despite the plea to stop development, in 2010, news of destructive soil excavation accompanied by large-scale tearing and cutting down of sacred trees caused outrage among elders of the Ramunangi clan. To make matters worse, the sacred falls were fenced off and the custodians were told they do not have the right to enter a construction area (Interview, custodian member, 28 April 2021).

Consequently, the Dzomo La Mupo committee was formed to defend and protect the network of sacred sites and, in particular, the Phiphidi Waterfall and surrounding forest. The committee recognised that the destruction of one sacred forest would lead to the destruction of other sacred natural sites because they are interlinked. According to their website, one of Dzomo La Mupo's objectives is to protect sacred natural sites against any destruction by people and preserve the earth for the benefit of all humanity. In response to the development on a sacred site, Dzomo La Mupo and elders of the Ramunangi clan filed an urgent application against Tshivhase Development Foundation 
Trust, Chief Tshivhase, Tshivhase Traditional Council, Traditional Leaders of Phiphidi, Jerry Tshivhase, the provincial Department of Economic Development and Tourism and the Minister of Rural Development and Land Reform (Interview, Mphatheleni Makaulula, 27 April 2021). The application was filed in the Limpopo High Court for an interim court interdict, requiring the developers to stop building the tourism complex at the sacred Phiphidi Waterfall and forest, pending a full hearing.

The interdict was granted but regardless of the interdict, the development continued. On 22 February 2011, following a breach of the court order, the South African High Court extended the temporary court interdict, instructing the builders to once again stop developing at Phiphidi Waterfall. Despite all the efforts that were made to stop construction at the sacred site, the development of the tourist lodge and associated facilities continued. The construction has caused massive destruction to the indigenous vegetation that has existed for millions of years (Interview, custodian member, 28 April 2021). R300 or R380 (depending on the size of the room) reserves or obtains you a room in one of the 18 cottages built in the area, R400 per day is charged for booking the lapa and R50 gives you access to the waterfall. Although Phiphidi Waterfall covers a small area, a large number of people ( $>8000$ people per year) are permitted to freely wander, even in the most sacred areas (Figure 2). This has been a cause of disagreement between the Ramunangi clan and the developers.

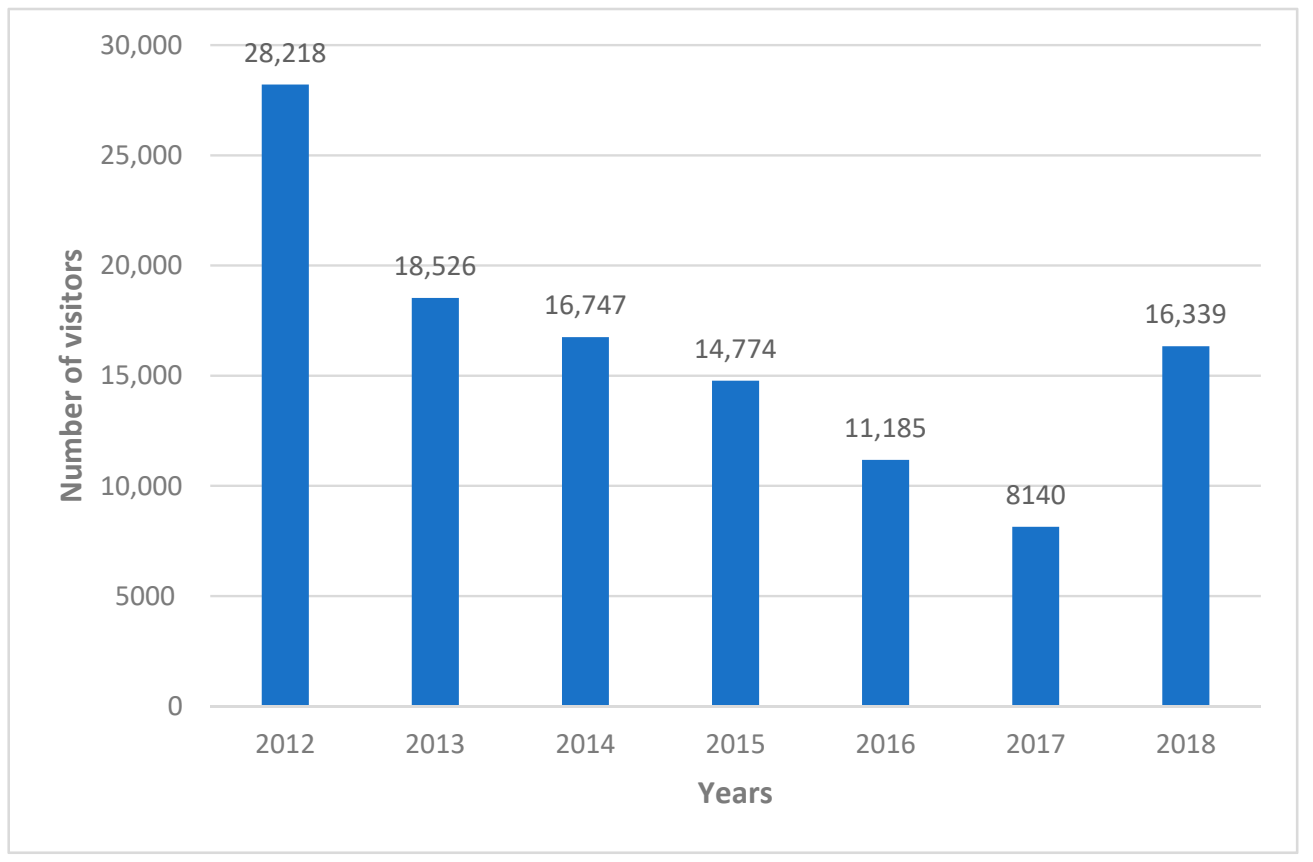

Figure 2. Annual number of visitors to Phiphidi Waterfall sacred natural site from 2012 to 2018.

The respondents interviewed indicated that the many tourists that have been allowed to enter Phiphidi Waterfall have trampled vegetation - particularly the shrubs and herbs that form the bottom layer of the forest. The interviewees were also of the view that the cars that are allowed to enter have also contributed to the destruction of vegetation in the area. There is also concern that tourists leave litter, cause water pollution and play loud music while inside the sacred forest. According to the Ramunangi clan, this is disrespectful, and these activities disturb the spirits (Interview, custodian member, 28 April 2021). Of particular concern to the Ramunangi clan is that their sacred site has become a 'lover's haunt' and the site is desecrated by used condoms. With regard to this, Makaulula Maphatheleni of Dzomo La Mupo asked the following critical questions:

'How can you change a sacred site into a hotel? Where should Zwidudwane (water spirits), snakes, owls, monkeys and other species stay? Many trees were cut during 
construction; therefore, where is the rain going to come from?' (Interview, Mphatheleni Makaulula, 27 April 2021).

The custodian respondents view the destruction of the sacred sites as a war waged against the ancestors and they warn that violating the sacred site could bring serious repercussions from the ancestors (Interview, custodian member, 28 April 2021). The Ramunangi clan is no longer performing their rituals in the area. As made clear by a custodian member:

We are not allowed to do our rituals in the area. How can we communicate with ancestors in the presence of tourists? We now do our rituals at home and it will never be the same again. It is no longer possible to do Thevhula in the area because Thevhula lasts for seven days and we are not required in the area. It is no longer possible to appease the ancestors in a place where there are houses and lights. Our ancestors do not want electricity, they do not want houses and they do not want people to freely wander in the area. Because we no longer practice our rituals in Phiphidi sacred site as we used to perform, our feet become so painful to the point of not being able to walk. This is a sign that our ancestors are not happy (Interview, custodian member, 28 April 2021).

As a result, the Ramunangi clan are concerned that famine, strife and disease will befall them because they have not been able to conduct their rituals properly in recent years. They regard the current plagues of sicknesses (referring to HIV / AIDs and coronavirus disease (COVID-19)) as being the direct result of insulting the ancestral spirits (Interview, custodian member, 28 April 2021).

\section{Discussion}

\subsection{Protection of Sacred Natural Sites}

Sacred natural sites constitute a vital part of indigenous communities' religion all over the world. Although they are accepted and respected by indigenous people, many sacred natural sites enjoy no legal protection [9]. Where there are laws or policies, they are not implemented to protect natural sacred sites. As a result, many sacred natural sites, particularly in the villages and communal land of indigenous people, are seemingly rendered 'invisible' and are threatened by anthropogenic activities, as this case study has demonstrated. Given the current threatened status of sacred sites in many parts of the world and their lack of recognition, one possible approach is the granting of juristic personhood or nature rights to protect sacred natural sites [47]. Personhood means that lawsuits to protect the land can be brought on behalf of the land itself. The purpose of granting juristic personhood or nature rights is to complement the community based customary ritual protection that is already in place [48]. In the case of the study area, although the custodian of the Phiphidi sacred natural site has filed an urgent application to protect the sacred natural site from development, they were unsuccessful, or their efforts have been ignored by courts. This happened despite the fact that South Africa is committed to culture and heritage rights as enshrined in the Constitution, as well as in the provisions of the South African Heritage Resources Act of 1999. Although this legislation helps to define the cultural identity that lies at the heart of spiritual well-being, as this case study has shown, it is not effectively implemented. This not only undermines the rights of communities, but also undermines the Constitution and the country's legal system (including its environmental laws). Unlike in the study area, where the legal system could not help to protect the sacred natural site, these innovations in law have allowed for 'nature rights' to be recognised in Ecuador and Bolivia, and 'juristic personhood' to be granted to biophysical entities in New Zealand, India and Colombia (Table 1). Although the African Commission on Human and Peoples' Rights resolved to protect sacred natural sites and territories in May 2017 [5], many sacred natural sites (including the Phiphidi sacred natural site) are not protected and continue to be threatened by various human activities. 
Table 1. The use of juristic personhood or nature rights to protect sacred natural sites in various parts of the world.

\begin{tabular}{ccc}
\hline Countries & Nature Rights & Juristic Personhood \\
\hline Ecuador & $\sqrt{ }$ & \\
\hline Bolivia & $\sqrt{ }$ & \\
\hline Zealand & & $\sqrt{ }$ \\
\hline India & & $\sqrt{ }$ \\
\hline Colombia & & \\
\hline
\end{tabular}

It is argued that the legal concept of personhood resonates with indigenous worldviews. Juristic personhood or nature rights is seen as a solution because it could create an interface and legal basis to bolster the effectiveness and endurance of sacred natural sites for the conservation of biodiversity [48]. In addition, the recognition of sacred natural sites as juristic persons with legal standing could lead to their recognition by the International Union for Conservation of Nature (IUCN). The result could lead to the protection of sacred natural sites under national law and recognition internationally, a benefit for nature conservation as well as indigenous people [48].

Another concept related to juristic personhood when dealing with the protection of sacred natural site is property rights. Thus, where the granting of juristic personhood is not feasible, as in the case of the study area, the literature suggests that property rights could be granted to the custodians of the sacred natural sites in recognition of their role in protecting the area. Over the past two decades, property rights have become an important issue when dealing with the protection of sacred natural sites [49-51]. The term 'property right' explains the legal and intellectual ownership of goods or asserts for income generation and/or consumption [52]. Ownership, according to this logic, gives the property owner the rights to use the property and/or exclude others from its use [53,54]. The literature suggests three main types of property rights, namely, private, communal or state $[55,56]$. While this definition may be correct for private property owners (individuals), it is not true particularly for communities on communal land. This is because-especially in southern Africa-communal lands are effectively administered as state land [57,58]. As a result, the rights to land in communal land is ill-defined, which makes it difficult for communities to negotiate their position [59].

In the case of the study area, the sacred natural site at Phiphidi is communal land that is administered by Chief Tshivhase. Although the Ramunangi clan are the acknowledged custodians and have protected the land where the sacred natural site is located for centuries, they do not hold the title deeds. As a result, over the past three decades, Phiphidi sacred sites have been affected by the widespread encroachment of human activities, as is the case on American Indian sacred sites [50,51] and sacred groves in South India [53]. This has limited the custodians' rights to continue their traditional practices. The anthropogenic activities happening in the area have not only threatened these groups' culture, but also the biodiversity in the area. This is a cause for concern in a country such as South Africa that has a Constitution that encourages the freedom to exercise religious and cultural rights. Although the Constitution embraces culture and religion, this is only in theory and not in practice-as this case study has demonstrated.

\subsection{Spiritual Governance of Sacred Natural Sites}

Over the years, conservation has been practiced in formally protected areas. It is argued that if conservation is to be successful, it should not only focus on formally protected areas, but it should also include indigenous people's sacred natural sites. As a result, spiritual governance has become an important concept when dealing with the protection of sacred natural sites. Spiritual governance is a characteristic behavioural practice that is found among many of the world's indigenous people [5]. In the case of sacred natural sites, 
behavioural practice constitutes the behaviour enjoined by the spirits or the behaviour that is allowed or not allowed in sacred natural sites. Thus, the power that protects the sacred natural sites does not live with the people but with the spirits and the spirits do not ask for permission from the people. Although the spirits are autocratic in terms of governance, they are dependent upon the people (owners and custodians) as their main actors. For instance, the owners and custodians of the sacred natural sites in China should engage in invocation rituals and liturgies on an annual basis [5]. In return, the custodians receive blessings, patronage, their own protection, as well as the protection of the sacred natural sacred site by the spirits. According to this logic, it is clear that spiritual governance is a prerequisite for protecting the biocultural integrity of indigenous sacred natural sites.

As in the case of China, in the study area, rituals in the form of Thevhula used to be performed on an annual basis for seven days as a prerequisite for good rain, health, agricultural abundance and community peace. The spiritual governance of the Phiphidi sacred natural site was complemented by the system of taboos that had ensured the area remained in a natural or near-natural condition for centuries. Negi [60] also found that the system of taboos had played a significant role in local resource management and conservation of the surrounding sacred natural sites in Uttarakhand, Central Himalaya. Unfortunately, the tourism development at the Phiphidi sacred natural site has made Theohula (an annual event) impossible because the custodians are no longer required in the area because the area is now a tourist destination area. Importantly, it is impossible to perform Thevhula in an area where there are houses and lights, and where tourists wander on a daily basis. Since this important event is no longer performed, in line with Ramble [61], it appears that the spirits are displaced and de-territorialised. In addition, the spirits have lost their power, status, authority and patronage. This is a sad reality that is making the feet of custodians (particularly elders) become painful to the point of not being able to walk. The tourism development at the Phiphidi sacred natural site undermines the ability of the custodian to protect their sacred site (including its biodiversity).

\subsection{Land-Use Conflicts}

Sacred natural sites are found in human-dominated landscapes. As a result, land-use conflicts are unavoidable. These conflicts happen whenever conflicting land-use stakeholders/parties have incompatible interests/uses for geographical units of land [62,63]. Sacred natural sites frequently prompt land-use conflicts. Rutte [20] has identified three main land-use conflicts in sacred natural sites, including competition over natural resources, modernisation versus traditional use and changing spiritual values. In the case of the study area, the conflict is between the custodians, whose intention it is to preserve a sacred natural site, and the developers, whose goal has been to use a sacred natural site for commercial gain. In line with the findings of Rutte [20], based on new market conditions, the developers deem the economic value of the sacred site to be greater than the spiritual value. This has led to court cases by the custodians to try to stop the building of the tourism complex on the sacred site at Phiphidi Waterfall and forest. However, despite the efforts to stop development on the sacred site, this continued regardless, with the consequences including forest habitat and biodiversity loss.

The destruction of sacred natural sites is not unique in Phiphidi. Sacred natural sites are facing a variety of threats, including the exploitation of natural resources and physical destruction in many parts of the world [8,12,20]. For instance, in India, many sacred groves have been destroyed by commercial forestry operations [53]. Similarly, Roba [12] found that in southern Ethiopia, the expansion and teaching of Abrahamic religions (particularly Christianity and Islam) and the implementation of unsustainable infrastructural projects, as well as a modern educational system, have resulted in the waning of people's loyalty to Gadaa customary laws. This has been associated with encroachment onto sacred land where anthropogenic influences have damaged sacred shrines. These influences have devastating effects on the sustainability of sacred natural sites. 


\section{Conclusions}

This study has shown that the sacred natural site in Phiphidi has been used for ritual purposes for centuries by the Ramunangi clan, who are acknowledged ancient custodians of the area. The rituals and ceremonies that were, up until recently, performed by the custodian clan helped to maintain the potency of the sacred natural sites and this assisted with the conservation of the area. The spiritual governance that existed for years at the Phiphidi sacred site as well as the system of taboos and the fear of supernatural punishments that served as cultural codes for sacred sites had ensured the area remained in a natural or near-natural condition for centuries. Although the Ramunangi clan has preserved the Phiphidi sacred natural site for centuries, they do not hold the title deeds to the land where the sacred natural site is located. In other words, they are not legally recognised as the owner of the area, even though they have strong connections to, and interest in, the sacred sites. As a result, the tourism development that started in the early 1980s happened without consulting the custodians and this has undermined the cultural practices that had been observed since time immemorial. This created conflict between the custodians of the Phiphidi sacred natural site (whose intention it is to preserve the area) and the developers (whose aim it is to gain from the area financially).

Although the Limpopo High Court granted an interdict, requiring the developers to stop building on the sacred site, the development proceeded. This led to the destruction of flora and fauna, fragmentation of the habitat, soil erosion and water pollution. There is also concern that the area has become a 'lover's nest' where people litter and play loud music, despite the area being a sacred site-and these activities disturb and anger the spirits. It was noted by the custodians interviewed that the presence of houses or chalets and lights in the evening also annoys the ancestors, who want to remain in the dark. The current situation in Phiphidi Waterfall not only undermines the Ramunangi clan but also the Vhavenda culture in general; there are fears that other sacred sites in the region may also be targeted for tourism purposes. It also undermines the Constitution of the Republic of South Africa and the associated legal system that embraces cultural and religious rights.

To ensure that the sacred natural sites are protected, this study suggests that the custodians of such sites need to be legally recognised as the owner of the area. In addition, the existing laws that embrace culture and religion in the Republic should not only end on a piece of paper but rather should be implemented on the ground to help protect the existing sacred natural sites. Lastly, the government of South Africa should support the protection of the remaining sacred natural sites and recognise them in a way equivalent to the recognition given to churches.

Author Contributions: Conceptualization, N.I.S.; Data curation, N.I.S.; Formal analysis, N.I.S.; Investigation, N.I.S.; Methodology, N.I.S.; Project administration, N.I.S., T.M. and M.R.; Resources, N.I.S. and M.R.; Software, T.M.; Validation, N.I.S., T.M. and M.R.; Visualization, N.I.S.; Writingoriginal draft, N.I.S.; Writing-review \& editing, N.I.S. and M.R. All authors have read and agreed to the published version of the manuscript.

Funding: This research received no external funding.

Institutional Review Board Statement: Ethical review and approval were waived because permission to conduct this study was granted by the local authorities. It was threfore not important to get institutional approval.

Informed Consent Statement: Informed consent was obtained from all subjects involved in the study.

Data Availability Statement: The data presented in this study are available on request from the corresponding author.

Conflicts of Interest: The authors declare no conflict of interest. 


\section{References}

1. Matshidze, P.E. The Role of Makhadzi in Traditional Leadership among the Venda. Ph.D. Thesis, University of Zululand, Zululand, South Africa, 2013.

2. Fokwang, J.; Sharp, P.J. Chiefs and Democratic Transition in Africa: An Ethnographic Study in the chiefdoms of Tshivhase and Bali. Ph.D. Thesis, University of Pretoria, Pretoria, South Africa, 2003.

3. Sinthumule, N.I.; Mashau, M.L. Traditional ecological knowledge and practices for forest conservation in Thathe Vondo in Limpopo Province, South Africa. Glob. Ecol. Conserv. 2020, 22, e00910. [CrossRef]

4. Odhiambo, B.D.O.; Manuga, M. Tshatshingo pothole: A sacred Vha-Venda place with cultural barriers to tourism development in South Africa. Afr. J. Hosp. Tour. Leis. 2017, 6, 1-12.

5. Studley, J.; Horsley, P. Spiritual governance as an indigenous behavioural practice. In Cultural and Spiritual Significance of Nature in Protected Areas; Verschuuren, B., Brown, S., Eds.; Routledge: Abingdon, UK, 2018; pp. 72-81.

6. Ylhäisi, J. Traditionally Protected Forests and Sacred Forests of Zigua and Gweno Ethnic Groups in Tanzania; Department of Geography, University of Helsinki: Helsinki, Finland, 2006; ISBN 952103095X.

7. Wild, R.; McLeod, C. Sacred Natural Sites: Guidelines for Protected Area Managers; IUCN Publiation Services: Gland, Switzerland, 2008; ISBN 9782831710396.

8. Bhagwat, S.A.; Rutte, C. Sacred groves: Potential for biodiversity management. Front. Ecol. Environ. 2006, 4, 519-524. [CrossRef]

9. Oviedo, G.; Jeanrenaud, S.; Otegui, M. Protecting Sacred Natural Sites of Indigenous and Traditional Peoples. IUCN 2005, 77-100. Available online: https://www.iucn.org/sites/dev/files/import/downloads/sp_protecting_sacred_natural_sites_indigenous. pdf (accessed on 30 July 2021).

10. Kühnert, K.; Grass, I.; Waltert, M. Sacred groves hold distinct bird assemblages within an Afrotropical savanna. Glob. Ecol. Conserv. 2019, 18, e00656. [CrossRef]

11. Adeniyi, A.; Asase, A.; Ekpe, P.K.; Asitoakor, B.K.; Adu-Gyamfi, A.; Avekor, P.Y. Ethnobotanical study of medicinal plants from Ghana; confirmation of ethnobotanical uses, and review of biological and toxicological studies on medicinal plants used in Apra Hills Sacred Grove. J. Herb. Med. 2018, 14, 76-87. [CrossRef]

12. Roba, G.O. Anthropogenic menace on sacred natural sites: The case of Me'ee Bokko and Daraartu sacred shrines in Guji Oromo, Southern Ethiopia. Heliyon 2021, 7, e06460. [CrossRef] [PubMed]

13. Prashanth Ballullaya, U.; Reshmi, K.S.; Rajesh, T.P.; Manoj, K.; Lowman, M.; Allesh Sinu, P. Stakeholder motivation for the conservation of sacred groves in south India: An analysis of environmental perceptions of rural and urban neighbourhood communities. Land Use Policy 2019, 89, 104213. [CrossRef]

14. Sen, U.K.; Bhakat, R.K. Floristic composition and biological spectrum of a sacred grove in West Midnapore district, West Bengal, India. Shengtai Xuebao Acta Ecol. Sin. 2021, 41, 106-119. [CrossRef]

15. Helms, M.W. Sacred landscape and the early medieval European cloister: Unity, paradise, and the cosmic mountain. Anthropos 2002, 97, 435-453. [CrossRef]

16. Dudley, N.; Higgins-Zogib, L.; Mansourian, S. The links between protected areas, faiths, and sacred natural sites. Conserv. Biol. 2009, 23, 568-577. [CrossRef] [PubMed]

17. Gopal, D.; von der Lippe, M.; Kowarik, I. Sacred sites as habitats of culturally important plant species in an Indian megacity. Urban For. Urban Green. 2018, 32, 113-122. [CrossRef]

18. Verschuuren, B.; Furuta, N. Asian Sacred Natural Sites: Philosophy and Practice in Protected Areas and Conservation; Routledge: London, UK; New York, NY, USA, 2016; ISBN 9781138936294.

19. Studley, J. Uncovering the Intangible Values of Earth Care: Using Cognition to Reveal the Eco-Spiritual Domains and Sacred Values of the Peoples of Eastern Kham. In Sacred Natural Sites: Conserving Nature and Culture; Verschuuren, B., Wild, R., McNeely, J.A., Oviedo, G., Eds.; Earthscan: London, UK, 2010; pp. 107-118. ISBN 9781849776639.

20. Rutte, C. The sacred commons: Conflicts and solutions of resource management in sacred natural sites. Biol. Conserv. 2011, 144, 2387-2394. [CrossRef]

21. Maffi, L.; Woodley, E. Biocultural Diversity Conservation: A Global Sourcebook; Taylor \& Francis Group: London, OH, USA, 2010; ISBN 9781849774697.

22. Doffana, Z.D. Sacred natural sites, herbal medicine, medicinal plants and their conservation in Sidama, Ethiopia. Cogent Food Agric. 2017, 3, 1365399. [CrossRef]

23. Balée, W. The research program of historical ecology. Annu. Rev. Anthropol. 2006, 35, 75-98. [CrossRef]

24. Dudley, N.; Bhagwat, S.; Higgins-Zogib, L.; Lassen, B.; Verschuuren, B.; Wild, R. Conderservation of Biodiversity in Sacred Natural Sites in Asia and Africa: A review of the scientific literature I Bas Verschuuren-Academia.edu. In Sacred Natural Sites: Conserving Nature and Culture; Verschuuren, B., Wild, R., McNeeley, J., Oviedo, G., Eds.; Earthscan: London, UK, 2010.

25. Stara, K.; Tsiakiris, R.; Wong, J.L.G. The Trees of the Sacred Natural Sites of Zagori, NW Greece. Landsc. Res. 2015, 40, 884-904. [CrossRef]

26. Devi, N.B.; Lepcha, N.T.; Mahalik, S.S.; Dutta, D.; Tsanglao, B.L. Urban sacred grove forests are potential carbon stores: A case study from Sikkim Himalaya. Environ. Chall. 2021, 4, 100072. [CrossRef]

27. Basu, R. Studies on sacred groves and Taboos in Purulia district of West Bengal. Indian For. 2000, 126, $1309-1318$.

28. Bhagwat, S.A. Ecosystem services and sacred natural sites: Reconciling material and non-material values in nature conservation. Environ. Values 2009, 18, 417-427. [CrossRef] 
29. Avtzis, D.N.; Stara, K.; Sgardeli, V.; Betsis, A.; Diamandis, S.; Healey, J.R.; Kapsalis, E.; Kati, V.; Korakis, G.; Marini Govigli, V.; et al. Quantifying the conservation value of Sacred Natural Sites. Biol. Conserv. 2018, 222, 95-103. [CrossRef]

30. Wadley, R.L.; Colfer, C.J.P. Sacred forest, hunting, conservation in West Kalimantan, Indonesia. Hum. Ecol. 2004, 32, 313-338. [CrossRef]

31. Bhagwat, S.A.; Kushalappa, C.G.; Williams, P.H.; Brown, N.D. A landscape approach to biodiversity conservation of sacred groves in the Western Ghats of India. Conserv. Biol. 2005, 19, 1853-1862. [CrossRef]

32. Verschuuren, B.; Wild, R.; Oviedo, G.; Mcneely, J. Sacred Natural Sites: Conserving Nature and Culture; Routledge: Abingdon, UK, 2010.

33. Bhagwat, S.; Palmer, M. Conservation: The world's religions can help. Nature 2009, 461, 37. [CrossRef] [PubMed]

34. Ishii, H.T.; Manabe, T.; Ito, K.; Fujita, N.; Imanishi, A.; Hashimoto, D.; Iwasaki, A. Integrating ecological and cultural values toward conservation and utilization of shrine/temple forests as urban green space in Japanese cities. Landsc. Ecol. Eng. 2010, 6, 307-315. [CrossRef]

35. Ratiba, M.M. The Gods Will Get You-A Plea, Exploration and Assessment of Possibilities for the Rescuing of Phiphidi Waterfalls and Other Sacred Cultural Sites. Indilinga Afr. J. Indig. Knowl. Syst. 2013, 12, 142-159.

36. Nekhavhambe, T.J.; van Ree, T.; Fatoki, O.S. Determination and distribution of polycyclic aromatic hydrocarbons in rivers, surface runoff, and sediments in and around Thohoyandou, Limpopo Province, South Africa. Water SA 2014, 40, 415-424. [CrossRef]

37. Munyati, C.; Sinthumule, N.I. Cover Gradients and the Forest-Community Frontier: Indigenous Forests Under Communal Management at Vondo and Xanthia, South Africa. J. Sustain. For. 2014, 33, 757-775. [CrossRef]

38. Mucina, L.; Rutherford, M.C. The vegetation of South Africa, Lesotho and Swaziland; South African National Biodiversity Institute: Brummeria, South Africa, 2006.

39. Stacy, M. Phiphidi Waterfall—South Africa-Sacred Land. Available online: https://sacredland.org/phiphidi-waterfall-southafrica/ (accessed on 6 July 2021).

40. Etikan, I. Comparison of Convenience Sampling and Purposive Sampling. Am. J. Theor. Appl. Stat. 2016, 5, 1. [CrossRef]

41. Andrade, C. The Inconvenient Truth About Convenience and Purposive Samples. Indian J. Psychol. Med. 2021, 43, 86-88. [CrossRef]

42. Guest, G.; Bunce, A.; Johnson, L. How Many Interviews Are Enough?: An Experiment with Data Saturation and Variability. Field Methods 2006, 18, 59-82. [CrossRef]

43. Braun, V.; Clarke, V. Using thematic analysis in psychology. Qual. Res. Psychol. 2006, 3, 77-101. [CrossRef]

44. Kansteiner, K.; König, S. The role(s) of qualitative content analysis in mixed methods research designs. Forum Qual. Soz. 2020, 21, 1. [CrossRef]

45. Neuman, W.L. Social Research Methods: Qualitative and Quantitative Approaches, 7th ed.; Pearson Education Limited: Harlow, UK, 2000; Volume 30, ISBN 9781292020235.

46. Ramunangi Tribal Leaders, the Ramunangi Claim of Rights (Lanwadzongolo and Claim of Rights to the Sacred Sites of 2008 pp. 1-14. Available online: https://sacredland.org/wp-content/uploads/2017/07/Ramunangi-Claim-of-Rights_15Nov08.pdf (accessed on 11 August 2021).

47. Studley, J. Indigenous Sacred Natural Sites and Spiritual Governance: The Legal Case for Juristic Personhood; Routledge: Abingdon, UK, 2018.

48. Studley, J.; Bleisch, W.V. Juristic personhood for sacred natural sites: A potential means for protecting nature. Parks 2018, 24, 81-96. [CrossRef]

49. Posey, D.A.; Plenderleith, K. Commodification of the sacred through intellectual property rights. J. Ethnopharmacol. 2002, 83, 3-12. [CrossRef]

50. Yablon, M. Property rights and sacred sites: Federal regulatory responses to American Indian religious claims on public land. Yale Law J. 2004, 113, 1623-1662. [CrossRef]

51. Carpenter, K.A. A Property Rights Approach to Sacred Sites Cases: Asserting a Place for Indians as Nonowners. UCLA Law Rev. 2004, 52, 1061.

52. Besley, T.; Ghatak, M. Property Rights and Economic Development, 1st ed.; Elsevier BV: Amsterdam, The Netherlands, 2010; Volume 5, ISBN 9780444529442.

53. Chandrakanth, M.G.; Bhat, M.G.; Accavva, M.S. Socio-economic changes and sacred groves in South India: Protecting a community-based resource management institution. Nat. Resour. Forum 2004, 28, 102-111. [CrossRef]

54. Egan, B.; Place, J. Minding the gaps: Property, geography, and Indigenous peoples in Canada. Geoforum 2013, 44, 129-138. [CrossRef]

55. Bromley, D.W. Property relations and economic development: The other land reform. World Dev. 1989, 17, 867-877. [CrossRef]

56. Sinthumule, N.I. Resistance against conservation at the South African section of Greater Mapungubwe (trans) frontier. Afr. Spectr. 2017, 2, 53-77. [CrossRef]

57. Sinthumule, N.I. Land Use Change and Bordering in the Greater Mapungubwe Transfrontier Conservation Area; University of Cape Town: Cape Town, South Africa, 2014.

58. Sinthumule, N.I. Multiple-land use practices in transfrontier conservation areas: The case of Greater Mapungubwe straddling parts of Botswana, South Africa and Zimbabwe. Bull. Geogr. 2016, 34, 103-115. [CrossRef]

59. Ramutsindela, M.; Sinthumule, I. Property and Difference in Nature Conservation. Geogr. Rev. 2017, 107, 415-432. [CrossRef] 
60. Negi, C.S. The institution of taboo and the local resource management and conservation surrounding sacred natural sites in Uttarakhand, Central Himalaya. Int. J. Biodivers. Conserv. 2010, 2, 186-195.

61. Ramble, C. The Navel of the Demoness: Tibetan Buddhism and Civil. Religion in Highland Nepal; Oxford University Press: Oxford, UK, 2008.

62. Von Der Dunk, A.; Gret-Regamey, A.; Dalang, T.; Hersperger, A.M. Defining a typology of peri-urban land-use conflits-A case study from Switzerland. Landsc. Urban Plan. 2011, 149-156. [CrossRef]

63. Sinthumule, N.I.; Ratshivhadelo, T.; Nelwamondo, T. Stakeholder perspectives on land-use conflicts in the South African section of the Greater Mapungubwe Transfrontier Conservation Area. J. Land Use Sci. 2020, 15, 11-24. [CrossRef] 